\title{
NOWOŻYTNA HISTORIA JAPONII
}

Andrew Gordon, Nowożytna historia Japonii, przeł. Iwona Merklejn, Państwowy Instytut Wydawniczy, Warszawa 2010, ss. 496.

Nowożytna historia Japonii Andrew Gordona to druga pozycja na polskim rynku wydawniczym, po książce Katarzyny Stareckiej i Ewy Pałasz-Rutkowskiej (Japonia, Trio, Warszawa 2004), ujmująca w sposób kompleksowy współczesne dzieje Japonii. Bez wątpienia jest to cenna pozycja, a na jej pojawienie się zapewne czekał niejeden czytelnik, który mógł czuć pewien niedosyt po książce naszych polskich japonistek, napisanej dość encyklopedycznym stylem i odznaczającej się oszczędną analizą materiału historycznego. Na pochwałę zasługuje tłumaczka Iwona Merklejn - z zawodu japonistka - która doskonale przełożyła lekki styl narracji Gordona oraz fachowo posługuje się japońską terminologią na gruncie języka polskiego.

Najważniejsze przesłanie autora brzmi: historia Japonii stanowi część historii świata, zaś zjawiska społeczne w Japonii - choć niewątpliwie specyficzne - nie były jednostkowe w skali globalnej. Gordon bez litości rozprawia się z teoriami, które usiłują nadać Japonii atrybut „wyjątkowości”, a które tak długo dominowały w dyskursie japonistycznym i odcisnęły piętno także na polskiej nauce.

Mocną stroną książki jest to, że autor rozłożył po równo akcenty na zagadnienia społeczne, kulturowe i polityczne. Opisując stosunki społeczne - życie na wsi i w mieście, stosunki pracownicze, życie kulturalne i debaty intelektualne - Gordon doskonale odtworzył realia poszczególnych epok, pokazując zarazem, gdzie należy szukać przyczyn pewnych wydarzeń politycznych. Wyjaśnia na przykład, że to, iż Japonia zrobiła gwałtowny zwrot w prawo w latach 30 . XX wieku, nie było wynikiem sytuacji, że do władzy doszła grupa sfrustrowanych wojskowych, 
ale zmęczenia społeczeństwa przeciągającym się kryzysem gospodarczym, który nękał kraj całą dekadę lat 20. W takim klimacie odezwały się głosy krytykujące zdobycze demokracji z jednej strony, a z drugiej kwestionujące wolny kapitalizm i nawołujące do ręcznego sterowania gospodarką przez państwo. To sprzyjało podporządkowaniu machinie wojennej całego potencjału narodowego.

Książka podzielona jest na cztery części: Kryzys reżimu Tokugawów; Rewolucja nowożytna, 1868-1905; Imperium Japonii. Od dominacji do ruiny i Japonia powojenna i wspótczesna, lata 1952-2000. Warto zwrócić uwagę, iż Gordon rozpoczyna swoją opowieść nie od przewrotu Meiji (1868) - jak można by oczekiwać, zważywszy, że to wtedy Japonia wkroczyła w czasy nowoczesności - lecz cofa się do poprzedniej epoki, do czasów początku siogunatu Tokugawów, a więc ok. roku 1600. Gordon stoi na stanowisku, że aby zrozumieć fenomen Japonii okresu Meiji, należy dogłębnie poznać procesy społeczno-kulturowe okresu Edo, które zapoczątkowały erozję systemu bakuhan i stworzyły uwarunkowania przyszłej rewolucji. Dlatego poświęca okresowi Edo jedną czwartą książki. Pod tym względem stanowisko Gordona jest bliskie Mariusowi Jansenowi, który w swoim epokowym dziele The making of modern Japan poświęcił epoce Edo niemal pół książki. Wśród wewnętrznych przyczyn, jakie złożyły się na upadek siogunatu, Gordon wymienia rozwój mieszczaństwa, handlu, migrację, a także wykształcenie społeczeństwa, które zaczęło kontestować panujący porządek polityczny.

Część druga poświęcona jest przewrotowi Meiji. Gordon nazywa to wydarzenie rewolucją, zdając sobie sprawę, iż trochę na wyrost, jeśli będziemy myśleć o nim tak, jak myślimy np. o rewolucji francuskiej. Niemniej - pisze - zważywszy, jak Japonia wyglądała w chwili upadku siogunatu i dekadę później, przeobrażenia jakim uległa, w pełni zasługują na miano rewolucyjnych. Gordon zaznacza jednocześnie, że japońska rewolucja była częścią światowej rewolucji - technologicznej oraz w sferze stosunków gospodarczo-społecznych. To, co czyni ją inną od europejskich, to fakt, iż nie była to „rewolucja burżuazyjna”. Nie była to także „rewolucja arystokratyczna". Dokonała się ona rękoma samurajów średniego szczebla, którzy u schyłku epoki Edo żyli w ciągłej niepewności jutra i nie mieli wiele do stracenia.

W trzeciej części autor zastanawia się nad przyczynami, które pchnęły Japonię ku kataklizmowi II wojny światowej, omawia okres wojenny i kończy na amerykańskiej okupacji Japonii, która trwała do 1952 r. Włączenie lat okupacji do tej części książki jest ciekawym zabiegiem odzwierciedlającym świadomość historyczną Japończyków, dla których okres powojenny - kojarzony z dobrobytem i szybkim rozwojem - zaczyna się dopiero od traktatu San Francisco i odzyskania przez kraj suwerenności. Opisując lata 30., Gordon dostrzega wiele analogii pomiędzy tym, co zaszło w Japonii oraz w faszystowskich Niemczech i Włoszech. Ponadto Gordon rozprawia się z pielęgnowanym przez Japończyków mitem, jakoby do kata- 
strofy Japonii przyczynili się wyłącznie militaryści. Autor podkreśla rolę elit biurokracji oraz przedstawicieli wielkiego biznesu - niegdyś celów ataków ze strony prawicowych ekstremistów - którzy dogadali się z militarystami.

Ostatnia część obejmuje lata od 1952 do czasów najnowszych. Tu autor stara się m.in. znaleźć odpowiedź na pytanie o „cud gospodarczy”, które od lat zaprząta głowę ekonomistów i badaczy Japonii. W tej części więcej uwagi poświęcone zostało zagadnieniom ekonomicznym, obfituje ona w liczby i tabelki, ale bynajmniej nie jest nużąca. Gordon zwraca uwagę na interesujący fakt, mianowicie na ciągłość przedwojennych stosunków polityczno-społeczno-ekonomicznych, które zostały zachowane pomimo ambitnych planów Amerykanów przeobrażenia Japonii w demokratyczne społeczeństwo. Nie chodzi tylko o to, że Amerykanom nie udało się rozbić struktur zaibatsu. Gordon zauważa, że aż do końca lat 50. stosunki społeczne w Japonii były bliższe okresowi lat 30. niż 70. Dlatego wprowadza pojęcie „systemu transwojennego" (transwar system), obejmującego te aspekty życia społeczno-gospodarczego, które przetrwały wojnę, a nawet przyczyniły się do powojennego rozwoju kraju. Gordon wskazuje tu m.in. na interwencjonizm państwa, które czerpało z wielu rozwiązań systemowych z lat 30. Oczywiście, patrząc z dzisiejszej perspektywy, Japonia uległa dramatycznym przemianom, ale państwo - w bliskiej współpracy z kręgami biznesu - przez długie lata zachowało rolę inżyniera społecznego, rozdzielając role społeczne i genderowe i starając się kierować procesem przemian, tak jak to czyniło w latach przedwojennych.

Gordon przyznaje, że japoński cud gospodarczy jest swego rodzaju fenomenem. Przestrzega jednak przed ubieraniem Japonii w teorie, jakoby był to kraj niezwykły, unikatowy i odmienny niż reszta świata. Postapimy stusznie - pisze - patrząc na doświadczenia Japonii jak na coś fascynującego, ale nie bezwzględnie wyjątkowego. Byty one wariacjami na - nabierajacy coraz bardziej globalnego znaczenia - temat radzenia sobie z nowoczesnościa i bogactwem.

Warto odnotować, iż autor poświęcił odrobinę uwagi geograficznym i kulturowo-społecznym peryferiom Japonii: Okinawie, Hokkaido, społeczności pariasów burakumin i Koreańczykom. Jest to o tyle istotne, że w dawniejszych opracowaniach historii Japonii temat ten był niemal całkowicie pomijany, a naukowcy nolens volens przyzwyczaili nas do myślenia o Japonii jako „kraju homogenicznym”. Gordon ledwo sygnalizuje tematykę mniejszości, ale przynajmniej zmusza do krytycznego spojrzenia na utarty wizerunek Japonii.

Wnikliwy czytelnik zwróci uwagę na bardzo ubogi wybór japońskich źródeł. Należy jednak pamiętać, iż temat podjęty przez Gordona nie jest ani nowy, ani wąski. Badacze Japonii dysponują olbrzymim korpusem wiedzy na temat Japonii spisanej w języku angielskim, a przy tak szerokim temacie, jakim jest kompleksowe ujęcie historii, nie ma sensu wyważać otwartych drzwi. Główny atut książki tkwi 
nie w źródłach, lecz w nowatorskim ujęciu historii - interpretacji procesów społecznych, z których narodziła się współczesna Japonia.

Autor posiada szeroką wiedzę i wnikliwy zmysł obserwacyjny, niemniej nie uchronił się przed popełnieniem kilku błędów merytorycznych. Na stronie 427 pisze: [Rząd] z zadowoleniem powitat najniższa wartość waluty japońskiej $w$ historii-znacznie poniżej stu jenów za dolara w 1995 r. - w nadziei, że to wspomoże eksport. [...] Silna gospodarka amerykańska i tani jen pobudziły eksport [...]. Jest to ewidentny błąd. W roku 1995 japońska waluta osiągnęła rekordowo wysoki kurs (79 JPY za 1 USD), co fatalnie odbiło się na japońskim eksporcie. Tu warto odnotować, że w nowym angielskojęzycznym wydaniu książki (2009) błąd ten został skorygowany. Inny błąd: pisząc o skandalu w Ministerstwie Zdrowia, które zaniedbało procedury bezpieczeństwa podczas wprowadzania na rynek leków na hemofilię w połowie lat 80., autor podał liczbę 20 tys. pacjentów zarażonych wirusem HIV na skutek przyjmowania skażonych leków (s. 430) - oczywiście poprawna liczba wynosi 2 tys. Ponadto rażą drobne, acz liczne błędy językowe i interpunkcyjne, które powinny być wyłapane w toku prac redakcyjnych nad polskim tekstem. Cóż - w dobie inflacji druku jest coraz trudniej o dobrego redaktora prowadzącego, ale od Państwowego Instytutu Wydawniczego można oczekiwać więcej. Niemniej te i inne niedociągnięcia nie zaważają na ocenie całokształtu pracy: książka jest świetna, powinna być obowiązkową lekturą dla studentów japonistyki i jest godna polecenia historykom oraz wszystkim badaczom wschodniej Azji. 